\title{
Farmers' Response on Field Performance of BSMRAU Developed IPSA Seem and BU Pepe1 Crop Variety
}

\author{
Md. Safiul Islam Afrad, Md. Amzad Hossain, Md. Enamul Haque, Md. Azizul Hoque, \\ Shahriar Hasan, Soumitra Saha, and Muhammad Ziaul Hoque
}

\section{ABSTRACT}

The study was conducted to investigate the adoption of IPSA seem and BU pepe1 crop variety by the farmers in Bhaluka upazila of Mymensingh and Meherpur Sadar upazila of Meherpur districts, respectively in Bangladesh. In-person interviews with 80 respondents and two focus group discussions were carried out to collect data. According to study findings, the highest portion of the respondents were young aged, literate, had medium farm size, low farming experience, and organizational participation and their average annual income were Tk. 192850 and Tk. 200500 for IPSA seem and BU pepe1 growers, respectively. Extent of adoption was above fifty percent in both cases of IPSA seem and BU pepe1 whereas the extent of BU pepe1 adoption was higher than IPSA seem. Performance of IPSA seem and BU pepe1 was satisfactory to the farmers in terms of ease of handling, better marketability and adaptation to the environment, vigor, and better physical appearance. Majority of the IPSA seem and BU pepe1 respondents experienced a medium increase in crop yield while medium to high-income increase by cultivating those varieties. Majority of them had a low to moderate knowledge gap in cultivating IPSA seem and BU pepe1. The major problems faced by the farmers were pod borer infestation, common mosaic virus for IPSA seem while low germination percentage, common mosaic virus for BU pepe1. The study results showed that respondents with small farm sizes were more interested in adopting IPSA seem than others. So, engaging small farmers in cultivating IPSA seem would make this technology more available and popular among the farmers.

Keywords: Adoption, BSMRAU, BU pepe1, IPSA seem, Performance.
Submitted : June 25, 2021

Published : August 23, 2021

ISSN: $2684-1827$

DOI: $10.24018 /$ ejfood.2021.3.4.333

Md. Safiul Islam Afrad*

Dept. of Agril. Extension and Rural Development, BSMRAU, Gazipur-1706, Bangladesh.

(e-mail: afrad@bsmrau.edu.bd)

Md. Amzad Hossain

Dept. of Agril. Extension and Rural Development, BSMRAU, Gazipur-1706, Bangladesh.

(e-mail: amzadbsmrau1994@gmail.com) Md. Enamul Haque

Dept. of Agril. Extension and Rural Development, BSMRAU, Gazipur-1706, Bangladesh.

(e-mail: denamul_aer@bsmrau.edu.bd)

Md. Azizul Hoque

Department of Horticulture, BSMRAU, Gazipur-1706, Bangladesh

(e-mail: azizul@bsmrau.edu.bd)

Shahriar Hasan

Dept. of Agril. Extension and Rural Development, BSMRAU, Gazipur-1706, Bangladesh.

(e-mail: shahriar@bsmrau.edu.bd)

Soumitra Saha

Dept. of Agril. Extension and Rural Development, BSMRAU, Gazipur-1706, Bangladesh.

(e-mail: soumitra@ bsmrau.edu.bd)

Muhammad Ziaul Hoque

Dept. of Agril. Extension and Rural Development, BSMRAU, Gazipur-1706, Bangladesh.

(e-mail: mziahoque.aer@bsmrau.edu.bd)

*Corresponding Author

\section{INTRODUCTION}

Agriculture is not only the subject matter of supplying food for a family but also a business. Previously, agriculture was known as the production of crops and collection of yearround food. But now the agricultural problems are becoming more complex that hamper overall crop production. To keep human life running it is necessary to increase agricultural production. Along with the increased production of grain crops, high-yielding fruits and vegetables can play a vital role in meeting the nutritional demand of Bangladesh [1], [2].

According to [3], the general recommendation for intake of fruits and vegetables is at least 400 grams per person per day.
The people of Bangladesh consume a total of $126 \mathrm{~g}$ of fruit and vegetables daily which is far below the minimum daily requirement. That's why the development of high-yielding crop varieties is very important to ensure the demand for food and nutrition [2], [4]. In Bangladesh, fruit production increased from 1357.0 thousand metric tons in 1970-71 to 5018.0 thousand metric tons in 2016-17 [5]. Vegetable production also increased by 2.5 times. Ensuring food security has been one of the major goals of Bangladesh since its independence in 1971 when most of the people were living under the poverty line [6]. Adoption of high-yielding crop varieties by farmers is a solution to food insecurity [7]-[10]. The prevalent factor in enhancement in yield is stimulated by 
high-yielding varieties (HYV), irrigation, fertilizer, and other management technology [11]-[15].

Population pressure continues to place a severe burden on productive capacity [16]. Food demand is growing over time due to rapid population growth and in some cases income growth, placing pressure on agricultural production in developing countries [17], especially in Bangladesh [18]. To meet this demand, the use of improved agricultural technologies can enhance productivity [8], [19]. The growth of agriculture will depend more and more on yield-increasing technological change [20]. According to [21] and [22], improving the livelihoods of rural farm households through agricultural productivity in developing countries would remain an undiluted wish if the agricultural technology adoption rate is low. Hence, there is a need to adopt the proven agricultural technologies to flourish production as well as productivity and thereby the living condition of the rural poor [23].

Technological innovation is one of the major factors shaping agriculture, and it, along with institutional changes, not only shapes and improves the agricultural sector, but reduces poverty, and improves standards of living through increased productivity [24], [25]. Problems of poverty and food security that are rampant in rural communities can be reduced through improved agricultural productivity which is a very important method [26].

Though many modern technologies have been adopted in the agriculture sector of Bangladesh, still they are very insufficient as well as unfamiliar to the farmers [27]. Different research organizations are also developing new technologies to make agriculture more profitable. Among them, BARI, BRRI, BJRI, BTRI, BAU, BSMRAU, SAU are well known. Bangabandhu Sheikh Mujibur Rahman Agricultural University (BSMRAU) is one of the organizations that are working relentlessly in this regard. BSMRAU has been conducting basic and applied research since its inception as IPSA (Institute of Post Graduate Studies in Agriculture) to generate appropriate and sustainable technologies in the field of agriculture as well as disseminate and transfer generated technologies to the end-users through training and outreach program [19], [28]. BSMRAU released technologies are adapting with different climate stress condition, accepting by the farmers, and contributing to national food security, poverty reduction, and sustainable agro-rural development [19].

So far, BSMRAU has released 52 different crop varieties [29]. Among them, IPSA seem and BU pepe1 are renowned varieties adopted by the farmers in different agro-ecological areas. BU pepe1 was released in 2012 and its salient features are high yielding, gynoedioecious, produces $98.0 \%$ female plant, an oval-shaped, reddish color with a sweet taste and high market price. Another popular technology developed by BSMRAU (former IPSA) IPSA seem that was released in 1991. Its main features are high yielding, earlier maturity, more seeds, less disease infestation, low requirement of fertilizer, etc. [29]. But there is a dearth of information regarding the adoption level of these two crop varieties in farmers' conditions. The present study, therefore, investigated to assess the adoption of IPSA seem and BU pepe 1 in the farmers' field, their performance, obstacles, and prospects.

\section{Methodology}

\section{A. Locale of the Study}

Though BSMRAU developed technologies have been cultivating in different agro-ecological zones of Bangladesh, Meherpur Sadar Upazila was selected for IPSA seem while for BU pepe1, Bhaluka Upazila of Mymensingh was selected. The study locations were selected purposively because each of the specific BSMRAU technology has been adopted by the farmers of that areas.
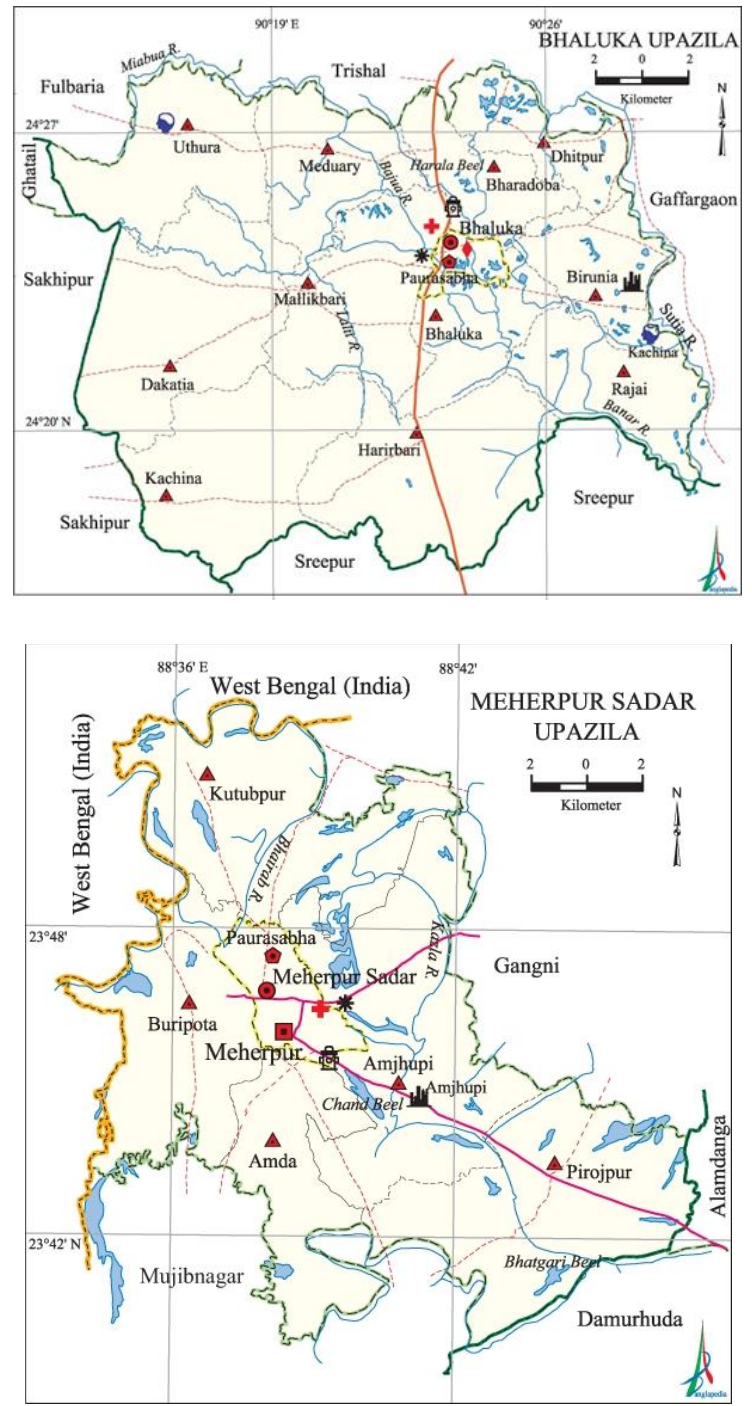

Fig. 1. Map of the study sites.

\section{B. Population and Sampling}

IPSA seem and BU pepe1 growers of the study sites were the target population of the present study. Lists of heads of all IPSA seem and BU pepe1 households of the selected areas were collected from the concerned Upazila Agriculture Extension Offices and Sub Assistant Agriculture Officers (SAAOs). From the collected lists, 40 farmers were selected randomly as a sample for each of BSMRAU technology. Thus, a total of 80 (40 individuals from each proposed study area) respondents were selected following a simple random sampling method.

\section{Data Collection Methods}

For the study, data were collected from the respondents 
through a face-to-face interview. All possible precautions were taken to avert bias and to maintain the fidelity of the responses. Statements were recorded what respondents said, not made judgments or comments on them. The objectives of the study were explained to them. At the time of the interview, the researcher asked each question steadily and whenever it was felt necessary. The questions were explained and clarified whenever any respondent felt difficulty in understanding. Two Focus Group Discussions (FGDs) were conducted in two locations for the collection of qualitative information to validate the findings.

\section{Performance of IPSA Seem and BU Pepe1 in Farmer's} Field

The performance of IPSA seem and BU pepe1 was measured in respondents' response percent on some selected characteristics which are relative advantage, compatibility, complexity, trial-ability, and observability. Here increased income, better marketability, ease of handling, the better taste was the scale of relative advantages following social compatibility, adaption to the environment, input requirement, and personal compatibility for the compatibility. Additional requirement of input, handling difficulty, complicated to understand were the parameters for the measurement of complexity following more time, input, the cost required for trial-ability. Observability was measured by the vigor and better physical appearance. Impact of performance was measured by percentage yield increase and percent income increase.

\section{E. Extent of Adoption}

A new technology adoption can be measured in different ways. [30] has constructed a multidimensional adoption scale to measure the rate of adoption of new technology. The scale covers both duration as well as area dimensions under the use of the particular practice under measurement. The formula constructed by [30] to compute the Adoption Quotient (AQ) for an individual has been adapted to express the $A Q$ in percent (multiplying the AQ by 100). The AQ can range from 0 to 100 , where 0 (zero) indicates no adoption of the practice and 100 indicates full adoption. The modified formula for calculating the AQ is presented below.

$\mathrm{AQ}=\frac{\mathrm{T}_{1}}{\mathrm{~T}_{3}} \times \frac{\mathrm{T}_{2}}{\mathrm{~T}_{3}} \times \frac{\mathrm{A}_{2}}{\mathrm{~A}_{1}} \times 100$

where,

$\mathrm{AQ}=$ Adoption Quotient;

$\mathrm{T}_{1}=$ Year since the practice under study was introduced;

$\mathrm{T}_{2}=$ Year since the user became aware of the practice;

$\mathrm{T}_{3}=$ Year since the practice was adopted by the user;

$\mathrm{A}_{1}=$ Potential area (acre/ha) under the practice during the surveyed year;

$\mathrm{A}_{2}=$ Actual area (acre/ha) under the practice during the surveyed year.

The extent of adoption of those technologies were measured from the above formula.

\section{F. Duration of Usage and Impact of a Technology}

The duration of usage of IPSA seem and BU pepe1 was measured by counting the years of practicing the technologies. A score of one (1) was assigned to each year.
Usage of IPSA seem and BU pepe1 was measured by computing the score of the respondents.

The advantage of innovation to the economy and production is the impact of technology. Increment of the total production was computed and also estimated total increased revenue of the technology. The lifestyle and socio-economic condition of a community can be upgraded through new technology. Therefore, the annual earning increment is one of the signs of a good technology as a positive impact.

\section{G. Knowledge Gap}

Farmers' agricultural knowledge referred to the understanding and acquaintance with different agriculturerelated activities. To assess the respondent's knowledge gap on different practices, fifteen questions were asked with two marks allotted for each. Total marks obtained by a respondent were added to evaluate their knowledge level. For a correct answer, a respondent was given two marks, and for a partial answer one mark. In case of an incorrect answer, a score of ' 0 ' was given. Knowledge gap was calculated by subtraction of obtained individual's marks from the total marks. Based on mean and standard deviation knowledge gap was categorized into the following:

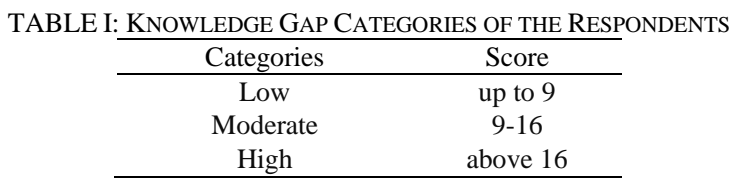

The respondents were asked about the problems which they faced while using the BSMRAU technologies. Respondents were also asked about the probable suggestions against each of the problems. The major problems they faced and offered suggestions were listed and ranked based on frequency.

\section{H. Processing and Analysis of Data}

After completion of the survey, all interview schedules were accumulated, and local units were converted into a standard unit. Appropriate scoring technique was followed to convert the qualitative data into quantitative data. All the collected data were classified, coded, compiled, and tabulated for processing and analysis following the objectives of the study. The SPSS/PC + statistix10 was used to perform the data analysis. [13] used a similar method for analyzing the data. Data were presented mostly in tabular forms, statistical measures like number, range, mean, and percentage for describing the data. Linear regressions were computed to indicate the contribution of selected characteristics of the respondents towards their adoption of IPSA seem and BU pepe1.

\section{RESULTS AND DISCUSSIONS}

\section{A. Farmers' Socio-demography}

The distribution of respondents (farmers) based on their socio-demographic characteristics has been shown in Table II. The age category showed that mainly young-aged farmers were involved in IPSA seem $(57.5 \%)$ and BU pepe1 $(45.5 \%)$ cultivation. Sixty percent $(60 \%)$ of the IPSA seem respondents were literate, and it was 57.5 percent for BU 
pepe1. Most of the IPSA seem respondents $(62.5 \%)$ belonged to medium family-size while most of BU pepe1 respondents $(47.5 \%)$ belonged to small family size. Most of the IPSA seem $(75 \%)$, and BU pepe1 $(67.5 \%)$ respondents possessed medium to large farm size. The average income of IPSA seem (BDT 192850), and BU pepe1 (BDT 200500) respondents were much higher than the national average (BDT 148518) [31]. In both cases, most of the farmers had low to medium farming experience. Data on training experience indicated that a portion of IPSA seem (42.5\%) and BU pepe1 $(37.5 \%)$ received training from NGOs and local agriculture office, and most of them received training of fewer than 2 days. Most percentages of the IPSA seem respondents (75\%) maintained contact with SAAOs while most of BU pepe1 respondents $(62.5 \%)$ kept a connection with friends/ family /relatives. The highest portion of the respondents (65\% for IPSA seem and $82.5 \%$ for BU pepe 1 ) had no organizational participation.

TABLE II: SOCIO-DEMOGRAPHIC FEATURES OF THE RESPONDENTS

\begin{tabular}{|c|c|c|c|c|c|c|c|}
\hline \multirow{3}{*}{ Characteristics } & \multirow{3}{*}{ Categories } & \multicolumn{4}{|c|}{ Respondents } & \multicolumn{2}{|c|}{ Mean } \\
\hline & & \multicolumn{2}{|c|}{ IPSA seem } & \multicolumn{2}{|c|}{ BU pepe1 } & \multirow{2}{*}{ IPSA seem } & \multirow{2}{*}{ BU pepe 1} \\
\hline & & No. & $\%$ & No. & $\%$ & & \\
\hline \multirow{3}{*}{$\begin{array}{l}\text { Age } \\
\text { (year) }\end{array}$} & Young $(\leq 35)$ & 23 & 57.5 & 18 & 45.5 & \multirow{3}{*}{37.2} & \multirow{3}{*}{40.0} \\
\hline & Middle $(36-50)$ & 17 & 42.5 & 12 & 30.0 & & \\
\hline & Old $(>50)$ & 13 & 32.5 & 07 & 17.5 & & \\
\hline \multirow{4}{*}{$\begin{array}{l}\text { Education } \\
\quad \text { (year) }\end{array}$} & Illiterate $(0)$ & 16 & 40.0 & 17 & 42.5 & \multirow{4}{*}{5.4} & \multirow{4}{*}{4.9} \\
\hline & Primary (1-5) & 05 & 12.5 & 03 & 7.5 & & \\
\hline & Secondary $(6-10)$ & 15 & 37.5 & 17 & 42.5 & & \\
\hline & $\begin{array}{c}\text { Higher secondary } \\
(>10)\end{array}$ & 04 & 10.0 & 03 & 7.5 & & \\
\hline \multirow{3}{*}{$\begin{array}{l}\text { Family Size } \\
\text { (Person) }\end{array}$} & Small $(<4)$ & 11 & 27.5 & 19 & 47.5 & \multirow{3}{*}{5.1} & \multirow{3}{*}{5.2} \\
\hline & Medium (4-6) & 25 & 62.5 & 14 & 35.0 & & \\
\hline & Large $(>6)$ & 04 & 10.0 & 07 & 17.5 & & \\
\hline \multirow{3}{*}{$\begin{array}{l}\text { Farm Size } \\
\text { (Hectare) }\end{array}$} & Small (up to 1.00) & 10 & 22.5 & 13 & 32.5 & \multirow{3}{*}{1.9} & \multirow{3}{*}{1.9} \\
\hline & Medium (1.01-3.00) & 26 & 65.0 & 18 & 45.0 & & \\
\hline & Large (Above 3.00) & 04 & 10.0 & 09 & 22.5 & & \\
\hline \multirow{3}{*}{$\begin{array}{l}\text { Annual Income } \\
\quad(\text { BDT })\end{array}$} & $\begin{array}{c}\text { Low (up to Tk. } \\
150,000)\end{array}$ & 19 & 47.5 & 22 & 55.0 & \multirow{3}{*}{192850} & \multirow{3}{*}{200500} \\
\hline & $\begin{array}{l}\text { Medium (Tk. 150,000 } \\
-300,000)\end{array}$ & 18 & 45.0 & 14 & 35.0 & & \\
\hline & $\begin{array}{c}\text { High (Above Tk. } \\
300,000)\end{array}$ & 03 & 07.5 & 04 & 10.0 & & \\
\hline Farming & Low (up to 16) & 23 & 57.5 & 26 & 65.0 & \multirow{3}{*}{18.4} & \multirow{3}{*}{16.8} \\
\hline \multirow{2}{*}{$\begin{array}{l}\text { Experience } \\
\text { (Year) }\end{array}$} & Medium (16-35) & 14 & 35.0 & 09 & 22.5 & & \\
\hline & High (Above 36) & 03 & 07.5 & 05 & 12.5 & & \\
\hline \multirow{3}{*}{$\begin{array}{c}\text { Training } \\
\text { Experience } \\
\text { (Day) }\end{array}$} & NGOs & 05 & 12.5 & 06 & 15.0 & & \\
\hline & $\begin{array}{c}\text { Upazila Agriculture } \\
\text { Office }\end{array}$ & 12 & 30.0 & 09 & 22.5 & 1 & 1.4 \\
\hline & No training & 23 & 57.5 & 25 & 62.5 & & \\
\hline & Up to 2 days & 10 & 25.0 & 08 & 20.0 & & \\
\hline Training & 3 to 4 days & 05 & 12.5 & 04 & 10.0 & 13 & 14 \\
\hline duration & 5 days and above & 02 & 5.0 & 03 & 7.5 & 1.3 & 1.4 \\
\hline & No training received & 23 & 57.5 & 25 & 62.5 & & \\
\hline & NGO & 06 & 15.0 & 17 & 42.5 & & \\
\hline & $\mathrm{AEO}$ & 17 & 42.5 & 10 & 25.0 & & \\
\hline $\begin{array}{l}\text { Intormation } \\
\text { Source }\end{array}$ & SAAO & 30 & 75.0 & 07 & 17.5 & - & - \\
\hline & Friends/family/relative & 17 & 42.5 & 25 & 62.5 & & \\
\hline & Fellow farmers & 12 & 30.0 & 23 & 57.5 & & \\
\hline Organizational & No member & 26 & 65.0 & 33 & 82.5 & & \\
\hline participation & Member & 14 & 35.0 & 07 & 17.5 & 0.4 & 0.2 \\
\hline
\end{tabular}

\section{B. Performance of the IPSA Seem and BU pepe1}

As stated by the highest portion of the respondents, both technologies had better marketability, ease of handling, and better taste. Most of them observed that both technologies were socially acceptable, adaptable with the environment, and personally compatible. The respondents perceived less complexity and trialability when they cultivated BU pepe1. Most percentages of them noticed vigor and better physical appearance in both technologies (Table III).

From this table, it is clear that BU pepe1 exhibited comparatively better performance than IPSA seem. Better performance of any technologies stimulates farmers to adopt it more rapidly and to a large extent. Similar findings are reflected in the study of [32], where increased family income, decent profitability, increased social reputation, better compatibility with the environment made BARI cowpea1 popular among farmers and positively influenced its adoption rate. Simultaneously, [33] witnessed a moderate to high adoption rate of BRRI dhan28 in coastal areas of Bangladesh due to its high market return, less-complex cultivation technique, high social acceptance, high yield, good trialability (short duration variety), the good physical appearance of grains, and good compatibility with the coastal environment.

\section{Usages, Extent of Adoption, and Impact of Technology}

Results presented in Table IV indicate that most of the IPSA seem respondents $(42.5 \%)$ practiced it for 4 to 6 years while major portion BU pepe1 respondents $(87.5 \%)$ practiced it for up to 3 years. The extent of adoption of BU pepe1 $(60 \%)$ was higher than IPSA seem $(52.7 \%)$. Most of the IPSA seem (45\%), and BU pepe1 (67.5\%) respondents experienced medium yield increment by utilizing the two technologies. 
However, most percentages of IPSA seem (75\%), and BU pepe1 $(85 \%)$ respondents experienced medium to highincome increment by utilizing them.

TABLE III: PERFORMANCE OF BSMRAU DEVELOPED TECHNOLOGIES (IPSA SEEM, BU PEPE1)

\begin{tabular}{clcc}
\hline \hline \multirow{2}{*}{$\begin{array}{c}\text { Perceived } \\
\text { attributes }\end{array}$} & \multicolumn{1}{c}{ Indicators } & \multicolumn{2}{c}{ Respondents (\%) } \\
\cline { 3 - 4 } & & $\begin{array}{c}\text { IPSA } \\
\text { seem }\end{array}$ & $\begin{array}{c}\text { BU } \\
\text { pepe1 }\end{array}$ \\
\hline \multirow{2}{*}{ Relative } & 1. Increased income & 15.40 & 18.00 \\
advantage & 2. Better marketability & 75.60 & 81.30 \\
& 3. Ease of handling & 78.50 & 77.30 \\
& 4. Better taste & 77.6 & 86.00 \\
\hline \multirow{2}{*}{ Compatibility } & 1. Social acceptability & 82.20 & 83.10 \\
& 2. Adaptation to environment & 85.50 & 86.50 \\
& 3. Additional input requirement & 1.00 & 3.00 \\
& 4. Personal compatibility & 77.50 & 76.00 \\
\hline \multirow{2}{*}{ Complexity } & 1. Handling difficulty & 12.40 & 18.30 \\
& 2. Complicated to understand & 10.00 & 13.10 \\
\hline \multirow{2}{*}{ Trial ability } & 1. More time requirement & 1.20 & 2.60 \\
& 2. More input requirement & 04.50 & 04.80 \\
& 3. More cost involvement & 04.50 & 05.10 \\
\hline \multirow{2}{*}{ Observability } & 1. Vigor & 75.00 & 77.80 \\
& 2. Better physical appearance & 81.00 & 85.00 \\
\hline \hline
\end{tabular}

BU pepe1 was a newly introduced variety in the study area; that's why its duration of usage ranged up to 6 years. In contrast, IPSA seem was an older variety and had been cultivating for more than 6 years.

High extent of adoption was observed in BU pepe1. It might be due to BU pepe1 showed better performance over IPSA seem in terms of relative advantage, compatibility, complexity, trialability, and observability. As BU pepe1 was a new variety, the extension personnel provided the respondents with better information regarding its cultivation which positively influenced its extent of adoption. [9] also observed high adoption of BARI-recommended potato varieties among farmers as proper extension services from GOs and NGOs increased their skills and knowledge of that technologies. Though the initiation of IPSA seems was not new but its expansion was not satisfactory. A similar scenario has been reflected in the study of [33] in BRRI dhan28.

Respondents' knowledge regarding proper crop management ensured the satisfactory yield of both varieties. As a result, a significant portion of the respondents experienced a medium to high-income increase after adopting those technologies. A study by [34] on BINA masur5 also noticed similar findings where farmers received a high return from it as they followed proper crop management guidelines during cultivation.

\section{Knowledge Gap}

An assessment of the respondents' technical knowledge regarding IPSA seems and BU pepe1 production has been presented in Table V. On average, respondents of both technologies exhibited a medium knowledge gap (mean score 11.8 and 12.0 for IPSA seem and BU pepe1, respectively). Most of the IPSA seem (85.0\%), and BU pepe1 (87.5\%) growers possessed low to a medium level knowledge gap on the cultivation technique of two technologies. The respondents possessed considerable knowledge on the farming of improved varieties. It might be due to a portion of them had agricultural training experience from whom other non-trained fellow workers got suggestions. Furthermore, they regularly kept contact with extension personnel of both
GOs and NGOs for improved farming tips. This knowledge motivated the farmers to adopt modern technologies. [33] also noticed that sound knowledge of the farmers on rice cultivation techniques inspired them to adopt BRRI dhan 28 to a large extent.

TABLE IV: USAGES, EXTENT OF ADOPTION, AND IMPACT OF BSMRAU TECHNOLOGIES

\begin{tabular}{cccc}
\hline \hline \multirow{2}{*}{ Attributes } & \multirow{2}{*}{ Categories } & \multicolumn{2}{c}{ Respondents (\%) } \\
\cline { 3 - 4 } & & IPSA seem & BU pepe1 \\
\hline \multirow{3}{*}{ Duration of usage } & Up to 3 years & 40.0 & 87.5 \\
& 4-6 years & 42.5 & 12.5 \\
& Above 6 years & 17.5 & 0.0 \\
\hline Extent of adoption & & 52.7 & 60.0 \\
\hline \multirow{2}{*}{ Yield increase } & Low (up to 10\%) & 45.0 & 32.5 \\
& Medium (11-20\%) & 45.0 & 67.5 \\
& High (above 20\%) & 10.0 & 0.00 \\
\hline \multirow{2}{*}{ Income increase } & Low (up to 3\%) & 25.0 & 15.0 \\
& Medium (4-6\%) & 37.5 & 47.5 \\
& High (above 6\%) & 37.5 & 37.5 \\
\hline \hline
\end{tabular}

\section{E. Constraints and Suggestions}

The respondents were asked to mention the problems they encountered while practicing the technologies and requested to opine suggestions on minimizing the problems. Results presented in Table VI represent the information on constraints and suggestions from the respondents of both varieties.

In the IPSA seem, pod borer infestation was recognized as a key problem faced by 78.0 percent of the respondents followed by a common mosaic virus attack (70\%). In contrast, most percentage $(82 \%)$ of BU pepe1 growers faced poor seed germination followed by the attack of common mosaic virus $(75 \%)$.

To combat the problems, the highest portion $(84 \%)$ of the IPSA seem growers suggested the development of pestresistant variety followed by providing training to the farmers $(76 \%)$. However, most of the BU pepe1 growers $(80 \%)$ recommended a variety with high germination percentage followed by the development of virus-resistant variety (78\%) and providing training facilities to farmers (55\%).

From these findings, it is evident that respondents of both technologies acutely suffered from pest attack and sought pest-resistant varieties. Adoptability of crops is negatively affected by frequent pest infestation which has also been reflected in the study of [32], [35]-[37]. Hence, researchers should emphasize this issue to make varieties less pest vulnerable.

Technical skill about improved production technology is very much vital for effective use of inputs and getting the desired yield. Lack of training acts as a barrier to obtain a high yield from improved varieties. Therefore, respondents of both varieties suggested hands-on training on those varieties' production. These findings are in line with the study of [37]. Simultaneously, in a study of [32] on BARI mung, farmers suggested to arrange training for them to combat pest problems more efficiently.

\section{F. Findings of Qualitative Study}

Two Focus Group Discussions (FGDs) were carried out in two locations to explore the salient features of IPSA seem and BU pepe1. A total of 30 farmers (15 individuals from each technology user respondents) were selected as participants. It 
was ensured that all of them willingly joined, and local leaders acted as moderators during the discussion sessions. Findings gathered from the focus group discussion have been presented in Box I.

TABLE V: RESPONDENTS' KNOWLEDGE GAP ON IPSA SEEM AND BU PEPE1 CULTIVATION

\begin{tabular}{ccccccc}
\hline \hline \multirow{2}{*}{ Knowledge } & \multicolumn{2}{c}{ Respondents (IPSA seem) } & \multicolumn{3}{c}{ Respondents (BU pepe1) } \\
\cline { 2 - 7 } & Frequency & Percent & Mean & Frequency & Percent & Mean \\
\hline Low (up to 9) & 9 & 22.5 & & 16 & 40.0 & \\
Medium (9-16) & 25 & 62.5 & 11.8 & 19 & 47.5 & 12.0 \\
High (above 16) & 6 & 15.0 & & 5 & 12.5 & \\
\hline \hline
\end{tabular}

TABLE VI: IDENTIFIED PROBLEMS AND OFFERED SUGGESTIONS FROM RESPONDENTS FOR BOTH BSMRAU TECHNOLOGIES

\begin{tabular}{ccccccc}
\hline \hline \multirow{2}{*}{ Innovation } & \multicolumn{5}{c}{ Respondent } \\
\cline { 2 - 6 } & Problems & $\%$ & Rank & Suggestions & $\%$ & Rank \\
\cline { 2 - 6 } IPSA seem & Pod borer infestation & 78.0 & $1^{\text {st }}$ & Insect and disease resistant variety & 84.0 & $1^{\text {st }}$ \\
& Common mosaic virus & 70.0 & $2^{\text {nd }}$ & Training facilities & 76.0 & $2^{\text {nd }}$ \\
& Wither away of flowers & 50.0 & $3^{\text {rd }}$ & Increase taste & 52.0 & $3^{\text {rd }}$ \\
& Thickening of stem & 42.0 & $4^{\text {th }}$ & & & \\
& Low germination percentage & 82.0 & $1^{\text {st }}$ & Increase germination percentage & 80.0 & $1^{\text {st }}$ \\
BU pepe1 & Common mosaic virus & 75.0 & $2^{\text {nd }}$ & Virus resistant variety & 78.0 & $2^{\text {nd }}$ \\
& Less compactness & 57.0 & $3^{\text {rd }}$ & Arrangement of training & 55.0 & $3^{\text {rd }}$ \\
& Lower taste & 30.0 & $4^{\text {th }}$ & More availability of seed & 37.0 & $4^{\text {th }}$ \\
\hline \hline
\end{tabular}

TABLE VII: CONTRIBUTION OF SELECTED SOCIO-ECONOMIC CHARACTERISTICS OF THE RESPONDENTS TO THEIR ADOPTION OF IPSA SEEM AND BU PEPE1

\begin{tabular}{|c|c|c|c|c|}
\hline \multirow[t]{2}{*}{ Variables } & \multicolumn{2}{|c|}{$\begin{array}{c}\text { Respondents of IPSA } \\
\text { seem }\end{array}$} & \multicolumn{2}{|c|}{ Respondents of BU pepe 1} \\
\hline & $\beta$ & $\mathrm{P}$ value & $\beta$ & $\mathrm{P}$ value \\
\hline Age & 0.168 & 0.75 & 0.10 & 0.82 \\
\hline Educational level & -.42 & 0.63 & -0.88 & 0.29 \\
\hline Family size & 1.47 & 0.65 & 0.07 & 0.96 \\
\hline Farm size & -2.26 & $0.01^{\text {** }}$ & -0.018 & 0.96 \\
\hline Total income & 2.74 & 0.92 & 4.03 & 0.99 \\
\hline Farming experience & .238 & 0.68 & -0.99 & 0.05 \\
\hline Constant & \multicolumn{2}{|c|}{50.38} & \multicolumn{2}{|c|}{76.75} \\
\hline $\mathrm{R}^{2}$ & \multicolumn{2}{|c|}{0.4321} & \multicolumn{2}{|c|}{0.2872} \\
\hline Adjusted R & \multicolumn{2}{|c|}{0.139} & \multicolumn{2}{|c|}{0.034} \\
\hline
\end{tabular}

**.05 level of significant.

\begin{tabular}{|c|c|}
\hline Salient features of IPSA seem & Salient features of BU pepe 1 \\
\hline $\begin{array}{l}>\text { Whitish green } \\
>\text { Better yield } \\
>\text { More seed } \\
>\text { Less disease infestation } \\
>\text { Collar rot }\end{array}$ & $\begin{array}{l}>\text { Reddish flesh } \\
>\text { Sweet taste } \\
>\text { High market price } \\
>\text { Very poor seed } \\
\text { germination rate } \\
>\text { Gap inflorescence }\end{array}$ \\
\hline
\end{tabular}

In the case of IPSA seem, respondents were satisfied with its better yield and seed production capability. Though it was comparatively more disease resistant than other varieties, respondents were a bit concerned about the collar rot problem. In comparison, sweet taste and high market price were the remarkable features of BU pepe1. But poor seed germination and the gap in inflorescence curtailed its popularity among growers. The FGDs finally concluded that identified characteristics of the two technologies were acceptable for adoption in the study areas.

Generally, the drivers intensely influenced farmers' adoption decisions about any technology were yield performance and profitability, biotic and abiotic stress tolerant capability, availability of good quality seeds, quality of crop product, and market demand [36], [38]. In most cases, better yield acts as a chief driving force behind adopting any technology because high yield ensures high returns and ultimately reduces poverty among farmers [39].

\section{G. Contribution of Selected Socio-economic Characteristics to the Adoption of IPSA Seem and BU pepe1}

This section explores the contribution of selected characteristics of the respondents towards their adoption of IPSA seem and BU pepe1 as presented in Table VII. Regression results indicated that nine variables together explain 43.21 percent variation in the adoption of IPSA seem. Out of nine characteristics, only farm size showed a negative significant contribution towards the adoption of IPSA seem. It means that small farmers were interested in the adoption of IPSA seem. This might be because of their direct contact with the farming operations and the adoption of new technologies as their own choice. Similar findings were observed by [35] on the adoption of mango variety. They found that farm size had a negative significant effect on the adoption level of BARI mango3 variety because large farmers had more options to choose other mango varieties. [36] also found that increase in farm size caused less adoption of BRRI rice varieties as larger farms choose more yielders like hybrid rice or Indian varieties and high-value rice like aromatic variety for high profitability. According to the study by [33], farm size had a negative and significant relationship with the adoption of BRRI dhan28. Contrarily, [38] and [40] observed reverse findings in their study that said an increase in farm size increased the probability of farmers adopting and intensifying the BRRI rice varieties. But findings of [9] were slightly different where education and knowledge regarding BARI potato varieties positively contributed to its adoption. 
In the same way, [41] noticed that educational level, annual family income, extension media contact influenced the adoption of BRRI dhan 49 by the farmers. On the other hand, nine variables together explain 28.72 percent variation in the adoption of BU pepe1. But none of the nine socioeconomic characteristics of the respondents showed significant contribution towards the adoption of BU pepe1.

\section{CONCLUSION}

Majority of the farmers (IPSA seem $57.5 \%$ and BU pepe 1 $45 \%$ ) were young aged and literate (IPSA seem 60\% BU pepe $157.5 \%$ ) with low to medium farm size (IPSA seem $90 \%$ BU pepe $182.5 \%$ ) having low farm experience (IPSA seem $57.5 \%$ BU pepe $165 \%$ ). Low organizational participation (IPSA seem 35\% BU pepe1 17.5\%) was found with an average annual income of Tk. 192850 and Tk. 200500 in case of IPSA seem and BU pepe1. Extent of adoption of BU pepe1 $(60 \%)$ was higher than IPSA seem $(52.7 \%)$. Majority (IPSA seem $78.5 \%$ and BU pepe $177.3 \%$ ) of the farmers found ease of handling and better marketability (IPSA seem $75.6 \%$, BU pepe $181.3 \%$ ), better adaptation to the environment $(85.5 \%$, BU pepe $186.5 \%$ ), and improved physical appearance (IPSA seem $81.0 \%$, BU pepe $185.0 \%$ ). Most of them (IPSA seem $45.0 \%$, BU pepe1 $67.5 \%$ ) experienced a medium yield increase. Most percentages of them (IPSA seem 75\%, BU pepe $185 \%$ ) experienced medium to high-income increase. A vital portion of the farmers (IPSA seem $85 \%$ and BU pepe1 $87.5 \%$ ) had a low to medium level knowledge gap in the cultivation of these two crops. Major problems faced by the farmers were pod borer infestation, common mosaic virus for IPSA seem and low germination percentage, common mosaic virus for BU pepe1. Important suggestions for improvement of IPSA seem were the development of insect and disease resistant variety and arrangement of training facilities while increase germination percentage and virus-resistant variety were for BU pepe1. Farm size was the only contributing factor that influenced their adoption of IPSA seem. That means the smaller the farm size of the farmers, the higher their adoption of IPSA seem.

\section{APPENDIX}

\section{Abreviations:}

AEO: Agriculture Extension Officer

AQ: Adoption Quotient

BARI: Bangladesh Agricultural Research Institute

BAU: Bangladesh Agricultural University

BBS: Bangladesh Bureau of Statistics

BDT: Bangladeshi Taka

BINA: Bangladesh Institute of Nuclear Agriculture

BJRI: Bangladesh Jute Research Institute

BRRI: Bangladesh Rice Research Institute

BSMRAU: Bangabandhu Sheikh Mujibur Rahman Agricultural University

BTRI: Bangladesh Tea Research Institute

FAO: Food and Agriculture Organization

FGD: Focus Group Discussion

GO: Governmental Organization

HYV: High Yielding Variety
IFAD: International Fund for Agricultural Development IPSA: Institute of Post Graduate Studies in Agriculture NGO: Non-Governmental Organization

SAAO: Sub Assistant Agriculture Officer

SAU: Sher-e-Bangla Agricultural University

SPSS: Statistical Package for the Social Sciences

\section{REFERENCES}

[1] M. Z. Hoque, M. A. Rahman, M. E. Haque, M. S. I. Afrad and M. M. Rahman, "Comparative contribution of crops and homestead forest enterprises to rural household economy: A case study of Keshorita Village in Bangladesh," Asian Journal of Advances in Agricultural Research, pp. 1-16, 2018.

[2] M. Z. Hoque, M. E. Haque, M. S. I. Afrad and M. A. M. Akanda, "Contribution of farming enterprises towards household food security in selected Charland of Bangladesh," Annals of Bangladesh Agriculture, vol. 17, no. 1 \& 2, pp. 47-56, 2013.

[3] FAO, Statistical Year Book 2013/2014, Rome: FAO, 2015.

[4] M. Afrin Sultana, S. I. Afrad, M. Z. Hoque and D. Bhattacharjee, "Knowledge of Farm Women on Nutritional Value of Farm Products in Bangladesh," Indian Research Journal of Extension Education, vol. 16, no. 2, pp. 25-30, 2016.

[5] BBS, Statistical yearbook of Bangladesh., Dhaka, Bangladesh: Bangladesh Bureau of Statistics, Ministry of Planning, 2017.

[6] IFAD, "Enabling poor rural people to overcome poverty in Bangladesh.," 2012.

[7] A. K. Singha and M. J. Baruah, "Farmers' adoption behavior in rice technology: An analysis of adoption behavior of farmers in rice technology under different farming systems in Assam.," Journal of Human Ecology, vol. 35, no. 3, pp. 167-172, 2011.

[8] M. Z. Hoque, M. E. Haque, M. S. I. Afrad and M. A. Hossain, "Adoption of farming technology by the Charland farmers," Bangladesh Journal of Extension Education, vol. 22, no. 1 \& 2, pp. 49-55, 2010.

[9] M. I. Khalil, M. E. Haque and M. Z. Hoque, "Adoption of BARI recommended potato (Solanum tuberosum) varieties by the potato farmers of Bangladesh," The Agriculturists, vol. 11, no. 2, pp. 79-86, 2013.

[10] W. Muzari, W. Gatsi and S. Muvhunzi, "The impacts of technology adoption on smallholder agricultural productivity in sub-Saharan Africa: A review," Journal of Sustainable Development, vol. 5, no. 8, p. $69,2012$.

[11] M. A. Kashem and M. A. A. Faroque, Agricultural technology: a challenge to way forward sustainable development, 2016.

[12] M. I. Khalil, M. E. Haque and M. Z. Hoque, "Adoption of recommended potato (Solanum tuberosum) production technologies by the potato growers of some selected areas of Bangladesh," Bangladesh Journal of Agricultural Research, vol. 39, no. 1, pp. 7992, 2014.

[13] S. S. Hasan, S. Roy, S. Saha and M. Z. Hoque, "Assessment of the farmers' perception on vermicompost as waste management practice and economic return in some areas of Bangladesh," European Journal of Agriculture and Food Sciences, vol. 3, no. 3, pp. 14-20, 2021.

[14] S. Hasan, M. E. Haque, M. S. I. Afrad, M. Z. Alam, M. Z. Hoque and M. R. Islam, "Pest risk analysis and management practices for increasing profitability of lemon production," Journal of Agriculture and Ecology Research International, pp. 26-35, 2021.

[15] S. Hasan, M. E. Haque, M. S. I. Afrad, M. Z. Alam, M. Z. Hoque and M. R. Islam, "Influences of socio-economic factors on lemon pest management practices in Tangail district of Bangladesh," South Asian Journal of Social Studies and Economics, pp. 59-67, 2021.

[16] P. K. Streatfield and Z. A. Karar, "Population challenges for Bangladesh in the coming decades," Journal of health, population, and nutrition, vol. 26, no. 3, p. 261, 2008.

[17] V. P. Gandhi and Z. Zhou, "Food demand and the food security challenge with rapid economic growth in the emerging economies of India and China," Food Research International, vol. 63, pp. 108-124, 2014. 
[18] M. Z. Hoque and M. E. Haque, "Farming practices in selected Charland of Bangladesh: problems and opportunities," Annals of Bangladesh Agriculture, vol. 15, no. 1 \& 2, pp. 136-146, 2011.

[19] F. A. Nasim, M. Z. Hoque, M. E. Haque, M. S. Islam, N. Parveen, S Chakma and M. S. I. Afrad, "How does adoption of crop variety reduce the impact of drought in agriculture and mitigate food insecurity of smallholder farmers? A case study on BU dhan1 rice variety in Bangladesh," Asian Journal of Agricultural Extension, Economics \& Sociology, pp. 1-12, 2019.

[20] M. Hossain, "Green revolution in Bangladesh: Impact on growth and distribution of income" Tabellen, University Press, 1989.

[21] O. C. Ajayi, S. Franzel, E. Kuntashula and F. Kwesiga, "Adoption of improved fallow technology for soil fertility management in Zambia: Empirical studies and emerging issues," Agroforestry Systems, vol. 59, no. 3, pp. 317-326, 2003.

[22] A. Gemeda, Farmers' maize seed systems in Western Oromia, Ethiopia, CIMMYT, 2001.

[23] M. Z. Hoque, S. Cui, L. Xu, I. Islam, J. Tang and S. Ding, "Assessing agricultural livelihood vulnerability to climate change in coastal Bangladesh," International Journal of Environmental Research and Public Health, vol. 16, no. 22, p. 4552, 2019.

[24] C. B. Barrett and M. R. Carter, "The power and pitfalls of experiments in development economics: some non-random reflections," Applied Economic Perspectives and Policy, vol. 32, no. 4, pp. 515-548, 2010.

[25] O. Bandiera and I. Rasul, "Social networks and technology adoption in northern Mozambique," The Economic Journal, vol. 116, pp. 869$102,2006$.

[26] S. Asfaw, B. Shiferaw, F. Simtowe and L. Lipper, "Impact of modern agricultural technologies on smallholder welfare: Evidence from Tanzania and Ethiopia," Food Policy, vol. 37, no. 3, pp. 283-295, 2012.

[27] M. Rahman, "Role of agriculture in Bangladesh economy: uncovering the problems and challenges," International Journal of Business and Management Invention, vol. 6, no. 7, pp. 34-46, 2017.

[28] M.S.I. Afrad and M.Z. Hoque, "Self-assessment of educational program for quality assurance: A case study on BS(Agriculture) program of BSMRAU," International Journal of Educational Research Review, vol. 5, no. 3, pp. 243-257, 2020.

[29] BSMRAU, "Bangabandhu Sheikh Mujibur Rahman Agricultural University (BSMRAU)," 2021. [Online]. Available: https://bsmrau.edu.bd/dres/varieties-released/.

[30] M. Wahab, "An analysis of factors influencing adoption and nonadoption of high yielding varieties of rice in Bangladesh," Thailand, 1979.

[31] BBS, Yearbook of agricultural statistics in Bangladesh, Dhaka: Ministry of Planning, Government of the People's Republic of Bangladesh, 2018.

[32] Q. S. Islam, M. M. Miah, M. S. Rahman and M. S. Hossain, "Adoption of BARI mung varieties and its constraints to higher production in southern region of Bangladesh," Bangladesh Journal of Agricultural Research, vol. 38, no. 1, pp. 85-96, 2013.

[33] M. K. Ghosh, "Adoption of BRRI dhan28 in the coastal areas of Bangladesh," International Journal of Agricultural Extension and Rural Development Studies, vol. 3, no. 3, pp. 25-35, 2016.

[34] S. Islam, M. H. Rahman, M. R. Haque, M. M. A. Sarkar and R. Sultana, "Technology adoption and profitability of BINA released lentil variety BINA masur5 in Bangladesh," South Asian Journal of Social Studies and Economics, vol. 8, no. 2, pp. 46-53, 2020.

[35] M. S. Rahman and M. Khatun, "Adoption and farmer's perceptions of BARI aam3 Mango variety in selected areas of Bangladesh," Research in Agriculture Livestock and Fisheries, vol. 5, no. 3, pp. 301-311, 2018 .

[36] M. S. Rahaman, M. J. Kabir, M. C. Rahman, M. A. R. Sarkar, M. A. Islam, M. A. Salam, M. I. Omar, M. S. Islam and M. A. B. Siddique, "Adoption determinants and constraint of BRRI released Aman rice varieties: Evidence from Mymensingh district," Journal of Bioscience and Agriculture Research, vol. 25, no. 1, pp. 2085-2097, 2020.

[37] M. S. Rahman, M. A. Hossain, M. J. U. Sarker and M. A. Bakr, "Adoption and profitability of BARI lentil varieties in some selected areas of Bangladesh," Bangladesh Journal of Agricultural Research, vol. 37, no. 4, pp. 593-606, 2012.

[38] M. S. Rahaman, M. J. Kabir, M. A. R. Sarkar, M. A. Islam, M. C. Rahman and M. A. B. Siddique, "Factors affecting adoption of BRRI released aus rice varieties in Mymensingh," Agricultural Economics, vol. 5, no. 5, pp. 210-217, 2020.

[39] M. A. Islam, M. C. Rahman, M. A. R. Sarkar and M. A. B. Siddique, "Assessing impact of BRRI released modern rice varieties adoption on farmers' welfare in Bangladesh: Application of panel treatment effect model," Bangladesh Rice Journal, vol. 23, no. 1, pp. 1-11, 2019.

[40] A. K. M. H. U. Chowdhury, M. E. Haque, M. Z. Hoque and M. Rokonuzzaman, "Adoption of BRRI dhan47 in the coastal saline areas of Bangladesh," Agricultural Journal, vol. 7, no. 5, pp. 286-291, 2012.

[41] M. A. Rahman, R. Islam, M. R. Falguni, S. A. Shahriar, M. A. Rahman and M. M. Rahman, "Adoption of BRRI dhan49 by the farmers of Bogura Sadar upazila in Bangladesh," Asian Journal of Research in Agriculture and Forestry, vol. 3, no. 2, pp. 1-8, 2019. 